Dataset Paper

\title{
Rainfall, Soil Water Content, and Groundwater Levels at the Riverlands Nature Reserve (South Africa)
}

\author{
Nebo Jovanovic, Richard D. H. Bugan, and Sumaya Israel \\ CSIR, Natural Resources and Environment, P.O. Box 320, Stellenbosch 7599, South Africa
}

Correspondence should be addressed to Nebo Jovanovic; njovanovic@csir.co.za

Received 2 April 2013; Accepted 21 April 2013

Academic Editors: A. Bhatnagar, K. M. Cohen, and M. Scholz

Copyright (C) 2013 Nebo Jovanovic et al. This is an open access article distributed under the Creative Commons Attribution License, which permits unrestricted use, distribution, and reproduction in any medium, provided the original work is properly cited.

\begin{abstract}
Quantified medium- and long-term hydrological datasets are scarce in South Africa, yet they are essential to gain understanding of natural systems, contribute to ecosystem conservation, and ultimately quantify water balance processes accurately. A hydrological experiment was carried out at Riverlands Nature Reserve (Western Cape, South Africa) in order to quantify the components of the soil water balance at experimental sites occupied by endemic and invasive vegetation. In two separate follow-up projects, five-year time series were collected in three treatments, namely, endemic fynbos vegetation, bare soil, and land invaded by Acacia saligna. Rainfall was recorded daily with a manual rain gauge. Groundwater levels were logged hourly at 14 boreholes. Volumetric soil water contents and soil temperatures were logged hourly at different depths in the soil profile. Groundwater levels and soil water contents responded to rainfall with very clear seasonal trends. The data can be applied in water balance and evapotranspiration studies, unsaturated flux studies, soil temperature profile studies, and rainfall-groundwater level response analysis and for calibrating and validating a wide range of hydrological models.
\end{abstract}

\section{Introduction}

The quantification of water resources and the water cycle are of utmost importance in water resources planning and management. Previous studies have indicated that water resources use and availability are dynamic depending on climate, population, land use, economic growth, technological change, and other socioeconomic factors [1]. It is therefore essential to monitor the components of the water balance in order to describe these dynamic trends. The importance of longterm monitoring in natural sciences is also acknowledged as this helps in understanding complex ecological systems and evaluating disturbances due to changes in land use, management, and climate [2]. Long-term monitoring also contributes to national and international networks for the largescale assessment of water resources [3]. This is particularly important when historic data are scarce, especially in arid regions that experience water stress, where knowledge of the water use of vegetation could have enormous implications to water resources management. Ultimately, monitored data are used in a variety of methods and models for water resources assessment, planning, and management interventions [4].
Alien invasive plants are species introduced in an area due to intentional or accidental human activity and have the potential to spread over a considerable area [5]. In recent years, areas invaded by alien plants have been increasing worldwide [6]. This is a concern both for human development (e.g., loss of agricultural production) and for impacts on biodiversity and natural ecosystems, with very large environmental and economic costs associated with alien species invasion [7]. It is currently recognized that invasive alien species have become a threat to biodiversity and ecosystem services, including water consumption, soil fertility, waste decomposition, and nutrient cycling $[8,9]$.

In South Africa, the extent of alien plants invasion is very large with an estimated 10 million hectares being invaded countrywide in 2000 [10]. However, the problem was only recognized once the effects of alien invasive plants on water and economic resources were demonstrated [11]. Alien invasive plants are usually species that are well adapted to climatic conditions, grow fast, are high water users, and impact on stream flow reduction through incremental water use (additional water use compared to natural vegetation) [10]. This is particularly critical in the Cape Floral Kingdom 

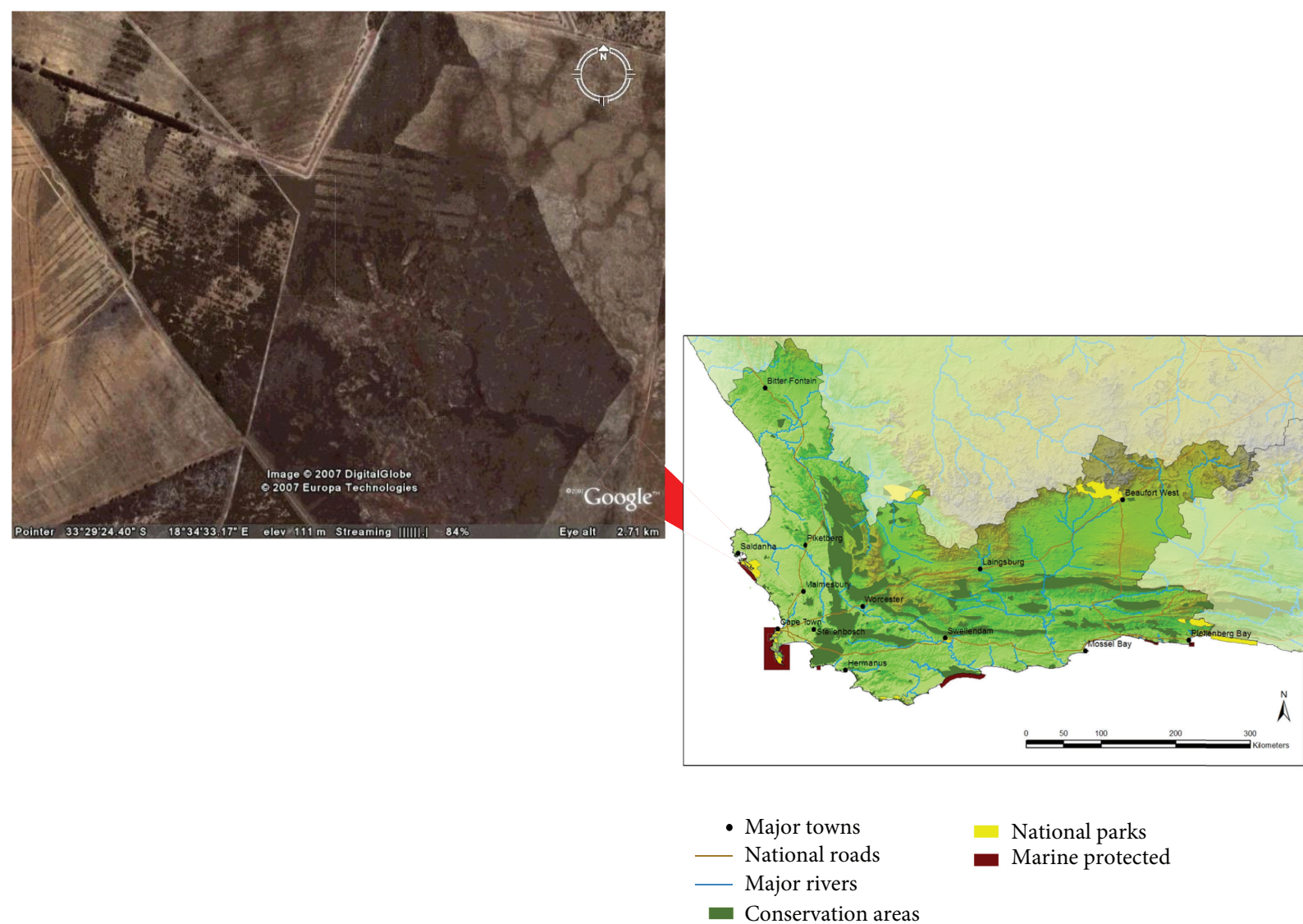

National parks
Marine protected

Conservation areas

Figure 1: Location of the Riverlands Nature Reserve on the Western Cape map of conservation areas. The white square in Google Earth indicates the experimental area.

(Western Cape Province, South Africa) that houses about 9000 endemic species of the fynbos and succulent karoo biomes [12]. Large areas have been invaded by Acacia saligna and Acacia cyclops, which were used to control drift sands from the mid-1800s up to the 1950s, often in areas that were denuded of vegetation by grazing and excessive burning. Competition for water between endemic and invasive species will become even tougher as future climate predictions indicate that the Western Cape region will become warmer, drier, and subject to more extreme droughts $[13,14]$, with potential risks of endemic species extinctions and range shifts [15].

Although it is difficult to express the value of clearing alien invasive species, the benefits are intuitive, like, for example, the intrinsic value of biodiversity, ecosystem goods and services, and the rights of future generations [16]. In 1996, the South African Department of Water Affairs initiated the Working for Water Programme, aimed at controlling woody invading alien plants to reduce water use and preserve stream flow in South African catchments [17]. Extensive areas of land are currently being cleared under this programme. Although it is generally accepted that clearing invasive alien vegetation in South Africa will have significant benefits in enhancing runoff from catchments, thus increasing the volumes of water available to people and ecosystems, quantified hydrological datasets are scarce.
As a result of these gaps, two research projects were carried out in the Riverlands Nature Reserve, managed by Cape Nature Conservation, located about $10 \mathrm{~km}$ South of Malmesbury (Western Cape, South Africa, Figure 1). The projects were funded by the South African Water Research Commission.

The first research project took place in 2007-2008, and its main objective was to assess nitrogen reserves in soils under alien vegetation and nitrogen movement in soils, subsoils, groundwater, and surface water after clearing [18]. As many alien invasive species targeted by the Working for Water Programme are nitrogen-fixing legumes (Fabaceae family), there is a distinct risk that clearing alien vegetation may lead to nitrate contamination of groundwater, with a consequent potential for negative health effects from consumed groundwater, and eutrophication of surface water bodies [19]. The second research project took place from 2009 to 2011 with the main aim of developing improved process-based estimates of groundwater recharge [20], where coupled atmospheric and unsaturated zone models were used to determine groundwater recharge, capillary rise from a shallow groundwater table, and its contribution to evapotranspiration of endemic fynbos [21].

Both research projects required intensive monitoring of the water balance. The monitoring programme was based on 
the principle of monitoring all environmental components as accurately as possible and for the longest possible period, namely, atmospheric, soil and vegetation, groundwater, and surface water [22]. The purpose of this paper is to collate and present rainfall, soil water content, and groundwater level data recorded at Riverlands for a relatively long period spanning from May 2007 until June 2012.

\section{Methodology}

Experimental location and set-up were the following. The Riverlands Nature Reserve is situated in a flat alluvial plane (slope $\sim 0.2 \%$ ) on Cenozoic deposits with Cape granite outcrops occurring in the surroundings. The soils are of marine and aeolian origin and are deep, well leached, generally acidic, and coarse sandy. The dominant vegetation type of the reserve is Atlantis Sand Plain Fynbos [23], one of the 11 forms of sand plain fynbos that occurs on the coastal plains of the western and southern coast of the Western Cape. The mean annual rainfall is $444 \mathrm{~mm}$, most of it occurring from May to August [23]. The mean daily temperature varies from about $7.0^{\circ} \mathrm{C}$ in July to $27.9^{\circ} \mathrm{C}$ in February, and there are about 3 days of frost per year. The mean annual pan evaporation is about $2150 \mathrm{~mm}$, and daily evaporation exceeds rainfall for about $70 \%$ of the time.

The vegetation is dominated by $1-1.5 \mathrm{~m}$ tall, emergent shrubs with a dense mid-storey of other shrubs and Restionaceae and a ground layer of recumbent shrubs, herbaceous species, geophytes, and grasses with occasional succulents. The vegetation structure is strongly controlled by the depth to the water table, both in areas where it is shallow and where it is deep [23]. Where the water table is very deep, the community is dominated by drought-hardy Restionaceae and, as the depth decreases, the incidence and cover of shrubs of the Asteraceae increases. Where the water table is shallower and shows little seasonal variation, the Proteaceae comprise the dominant shrubs and the canopy cover is higher. Where water tables become shallower, albeit seasonally, the community is dominated by Restionaceae and Cyperaceae (sedges). A comprehensive description of the site can be found in [18], including topography, soil classification, physical and chemical properties, and vegetation speciation, root depth, and canopy cover. Surface water, with the exception of occasional ponding in the low-lying areas, does not occur in this section of the catchment due to the sandy nature of the soil and high infiltration rates.

Intensive monitoring was established at a site across the boundary between the Burgerspost farm (invaded with predominantly $A$. saligna) and the fynbos nature reserve (Figure 2). Three treatments were established (Figure 2):

(i) a site cleared of alien species on 18 June 2007 (cleared treatment),

(ii) a site invaded by alien species to be used as control (uncleared treatment),

(iii) a site with natural vegetation to be used as background (fynbos treatment).

The geographic coordinates of the areas of the treatments can be found in [18].
Manual rainfall measurements were taken with rainmeters on a daily basis by Riverlands Nature Reserve. Additional weather data are available from a station located in Malmesbury (Figure 1), which is managed by the South African Weather Services.

Groundwater level measurements were as follows. A geophysical survey was carried out with LUND imaging resistivity meter in order to study the geological layering and the general direction of groundwater flow [18]. Boreholes were then drilled upstream, within, and downstream of each treatment (Figure 2) during the period from December 2006 to February 2007. Fourteen boreholes were established in total (RVLDn in Figure 2) and equipped with data loggers. Groundwater levels were measured with Leveloggers (model 3001; Solinst Ltd., Georgetown, Canada) and compensated for barometric pressure with a Solinst Barologger. The drilling techniques and borehole logs can be found in [18]. Additional six shallow well points were hand augered (RVLWPn in Figure 2); however, these were not equipped with loggers.

Borehole coordinates and other characteristics are summarized in Table 1. A water table elevation map (as on 28 February 2007) was then produced based on the measurements at 14 drilled boreholes, and it is overlaid in Figure 2. Groundwater flow direction is generally North-West to South-East. Slug tests, estimated aquifer hydraulic conductivity, and groundwater quality measurements (electrical conductivity, $\mathrm{pH}, \mathrm{Ca}^{2+}, \mathrm{Mg}^{2+}$, Kjeldahl $\mathrm{N}, \mathrm{NH}_{4}{ }^{+}, \mathrm{NO}_{2}{ }^{-}$and $\mathrm{NO}_{3}{ }^{-}, \mathrm{SO}_{4}{ }^{2-}, \mathrm{Cl}^{-1}, \mathrm{Fe}^{3+}$, dissolved organic carbon, alkalinity, and hardness) can be found in [18]. Manual measurements of groundwater levels were made with dip meters during each site visit, when loggers downloading took place, at least four times per year.

Soil measurements were provided as follows. In each treatment, continuous measurements of volumetric soil water content, soil temperature, and electrical conductivity were carried out with an Echo system (Decagon Inc., USA). The Echo system consisted of an EM50 logger and five EchoTE sensors that were buried at different depths in the soil to measure volumetric soil water content, soil temperature, and electrical conductivity of the soil solution. The DataTrac software (Decagon Inc., USA) was used to program the time, date, and measurement interval times of the EM50 logger and to download and chart data.

Five sensors were installed and connected to one EM50 logger at representative sites in each treatment. Three sensors were installed in a profile adjacent to the stem of bushes/trees (close to the main root system and below the bulk of the vegetation canopy), at depths of 5,40 , and $80 \mathrm{~cm}$. The other two sensors were installed in a profile 1 to $2 \mathrm{~m}$ away from the stem of bushes/trees and on patches clear of vegetation canopy, at depths of 5 and $80 \mathrm{~cm}$. The purpose was to get an idea of differences in water fluxes close and away from the bulk root system of vegetation and canopy in each treatment. Before installation, $30 \mathrm{~cm}$ diameter holes were augered. The sensors were inserted horizontally at the given depth into the wall of the hole in order to avoid the disturbed portion of the profile. Attention was paid to provide good contact between the probes and the soil. Air gaps, roots, and any other 


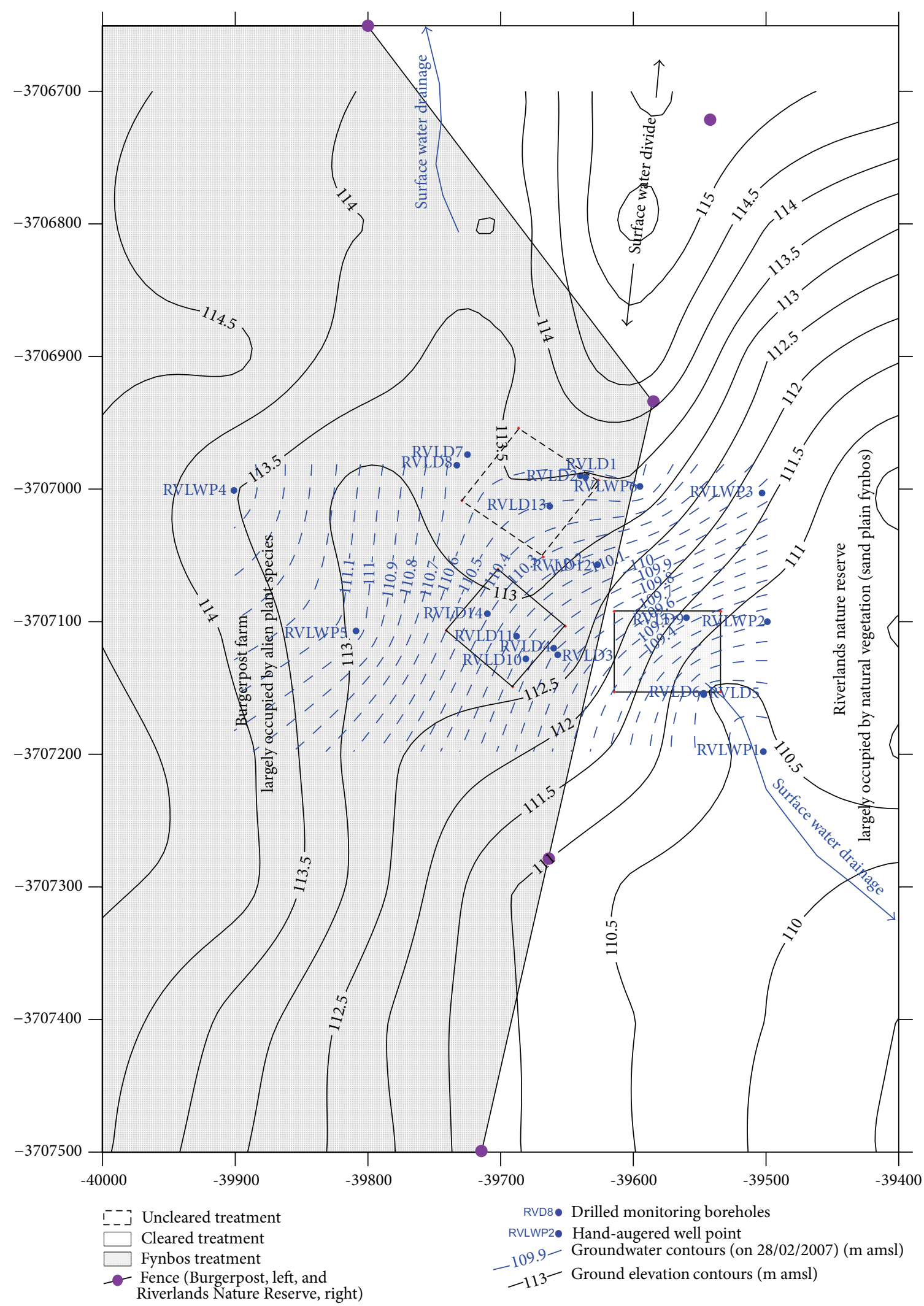

FIGURE 2: Map of experimental site (the coordinates are represented in the WGS 1984 reference positioning system, the projection is Transverse Mercator, the central meridian is 19.0, and the linear units are expressed in meters). 


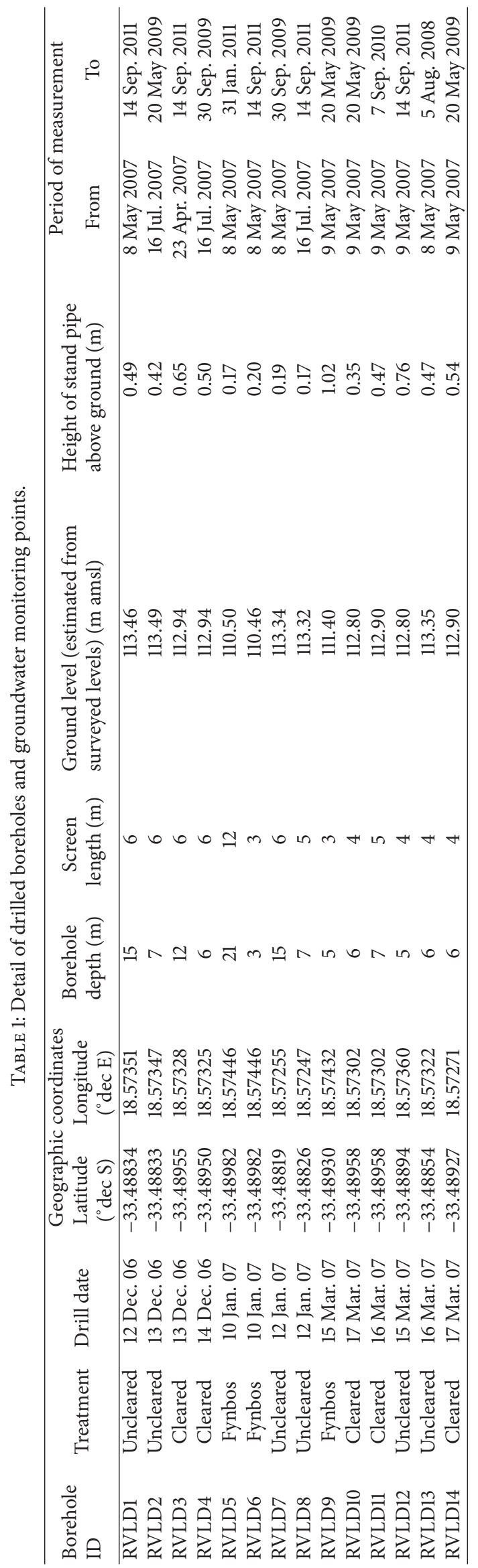


TABLE 2: Location and description of soil water content measurements at Riverlands with Echo-TE sensors installed at 5, 40, and $80 \mathrm{~cm}$ soil depth.

\begin{tabular}{|c|c|c|c|c|c|}
\hline \multirow{2}{*}{ Logger ID } & \multirow{2}{*}{ Coordinates $\left({ }^{\circ} \mathrm{dec}\right)$} & \multirow{2}{*}{ Altitude (m) } & \multirow{2}{*}{ Description } & \multicolumn{2}{|c|}{ Period of measurement } \\
\hline & & & & From & To \\
\hline EM3194 & $33.489574^{\circ} \mathrm{S} ; 18.573941^{\circ} \mathrm{E}$ & 112 & $\begin{array}{l}\text { Riverlands Nature Reserve; Flat Sand } \\
\text { Plain Atlantis Fynbos }\end{array}$ & 15 May 2007 & 31 Jan. 2011 \\
\hline EM3195 & $33.489582^{\circ} \mathrm{S} ; 18.573202^{\circ} \mathrm{E}$ & 113 & $\begin{array}{l}\text { Burgerposts Farm bordering with } \\
\text { Riverlands Nature Reserve; flat bare soil }\end{array}$ & 15 May 2007 & 1 Nov. 2010 \\
\hline EM3193 & $33.489108^{\circ} \mathrm{S} ; 18.573372^{\circ} \mathrm{E}$ & 114 & $\begin{array}{l}\text { Burgerposts Farm bordering with } \\
\text { Riverlands Nature Reserve; flat land } \\
\text { invaded by alien Acacia saligna }\end{array}$ & 17 May 2007 & 31 Jan. 2011 \\
\hline
\end{tabular}

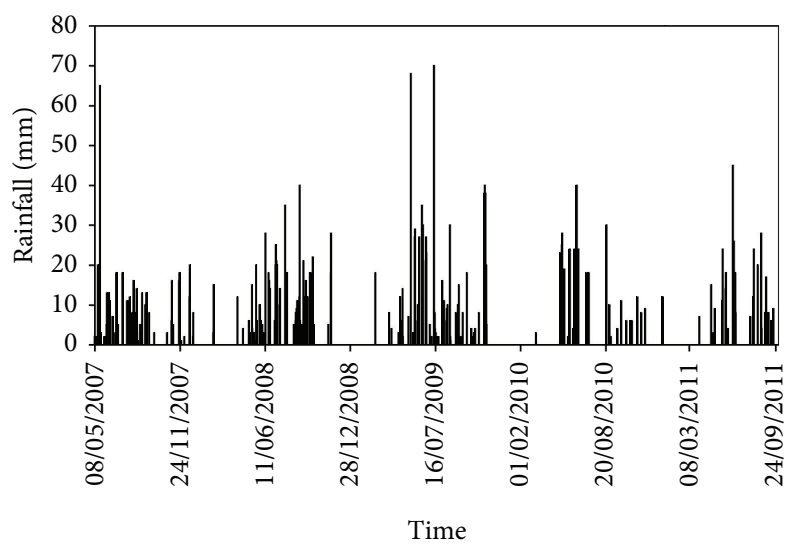

Figure 3: Daily rainfall measured with a manual rain gauge at Riverlands Nature Reserve from May 2007 to September 2011.

inconsistencies were avoided as this may have skewed the sensors' readings. The soil was repacked and compacted in the hole in the order it was dug, in order to regenerate a soil profile as close as possible to the original. The coordinates of the soil measurement stations are summarized in Table 2.

All sensors were set to record volumetric soil water content, soil temperature, and electrical conductivity every hour. The calibration supplied by the manufacturer for mineral sandy soils was used, and data were downloaded with the DataTrac software.

Daily rainfall data measured at Riverlands Nature Reserve are shown in Figure 3 for the period from 1 May 2007 to 19 September 2011.

Table 1 summarizes the metadata with borehole IDs, characteristics, and periods of measurements with Solinst loggers. The longest period of measurement was for the logger installed in borehole RVLD3 from 23 April 2007 to 14 September 2011. An interruption in logging occurred in the period from 28 March 2008 to 14 October 2009, during which the loggers were secured in boreholes. Logging resumed on 14 October 2009; some loggers were removed over time to be deployed at other experimental sites.

Figure 4 presents groundwater levels measured with Solinst loggers. Groundwater levels of the alluvial sandy aquifer responded to rainfall (Figure 4). They tended to increase with the onset of the rainy season and reached their

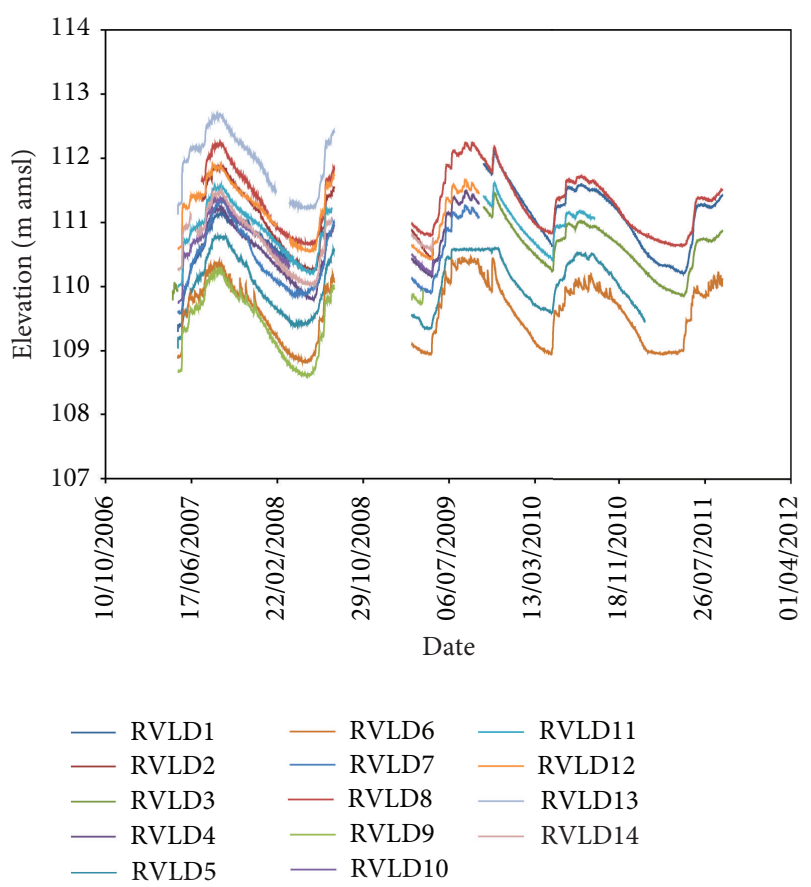

FIGURE 4: Hourly groundwater levels measured with Solinst loggers at Riverlands Nature Reserve from April 2007 to September 2011.

highest levels during the months from July to September. The groundwater levels decreased thereafter during the dry season, usually until April each year. The range of fluctuations in groundwater level was between 1 and $2 \mathrm{~m}$.

At a local scale, the overall differences in groundwater levels at all boreholes were less than $3 \mathrm{~m}$. The water table tracks elevation of the terrain and is generally shallow or rises to near or above the surface in localized depressions and lowlying areas during winter. In some cases, the groundwater level increased during winter and remained constant (e.g., RVLD5 in Figure 4). This indicated that the groundwater level reached the ground surface. This also results in marked topographically related patterns of the vegetation in line with the general trends described previously.

Table 2 summarizes the metadata with logger IDs, description, and periods of measurements with the Echo systems. Figure 5 represents the volumetric soil water contents measured at different depths in the soil profiles of fynbos, 


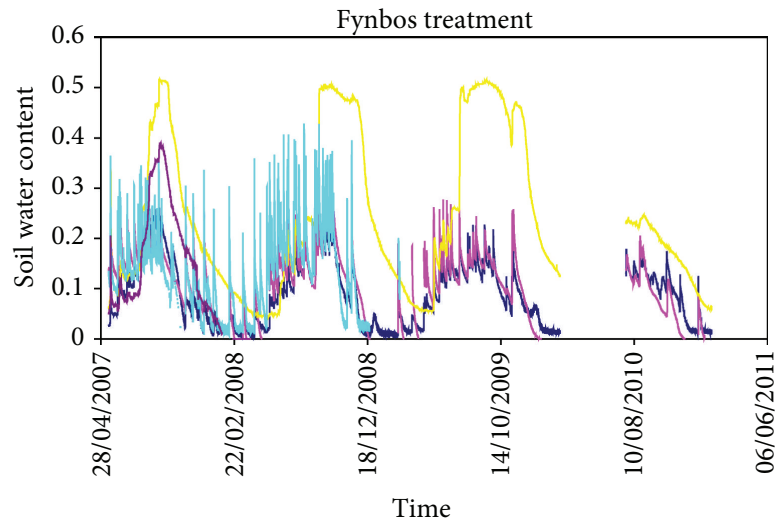

(a)

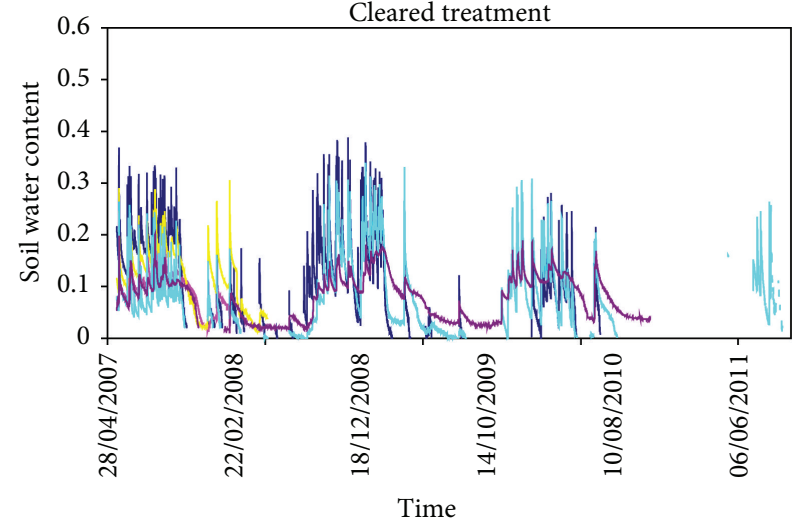

(b)

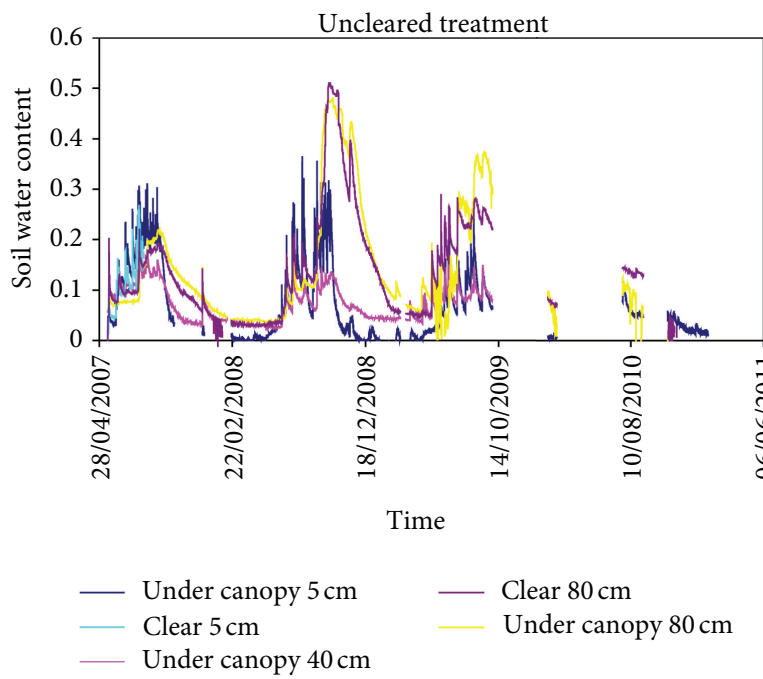

(c)

FIgURE 5: Volumetric soil water content measured from 1 May 2007 to 19 September 2011 with Echo-TE sensors at 5, 40, and 80 cm soil depth in three treatments at Riverlands Nature Reserve.

cleared, and uncleared treatments. All soil water content sensors responded to rainfall (Figure 3), but to a different extent depending mainly on the depth of installation. In particular, shallow sensors installed at $5 \mathrm{~cm}$ soil depth showed large increases of volumetric soil water content after rainfall. The response of the sensors installed at 40 and $80 \mathrm{~cm}$ was less pronounced depending on the amount of rainfall and the depth of wetting. The increases in volumetric soil water content after rainfall in the uncleared treatment were less pronounced compared to the cleared and fynbos treatments. This could be due to the positioning of the sensors under dense vegetation in the uncleared treatment. It should also be noted that water drained more rapidly and the soil water content dropped faster after rainfall events in the fynbos treatment compared to the other two treatments. This rapid release of water from soils in the fynbos treatment was also observed in water release curves obtained in the laboratory and it was due to the coarser texture of the soil in this treatment [18]. In general, volumetric soil water content had a tendency to increase during the winter months at all depths and in all treatments, due to rainfall and the reduced water use by vegetation (May to mid-September 2007). From midSeptember on, volumetric soil water content started decreasing sharply, first in the top soil layers followed by deeper layers. It is also evident from the data collected in the fynbos treatment (Figure 5) that a water table built up above the deepest measuring sensor ( $80 \mathrm{~cm}$ depth) in three out of four years. In 2007, the high water table occurred in September, whilst it lasted until November in 2008 and 2009. Some interruptions in sensors' recording are visible in Figure 5 and they were due to sensors' or loggers' malfunction.

Soil temperature may have an effect on organic matter and nutrient processes in soils, and this was also measured with Echo-TE sensors. Soil temperatures had a general tendency to decrease over time during the period from May to the beginning of August (Figure 6). During this period, they were consistently higher in deeper soil layers compared to shallow ones, indicating inverse temperature profiles that are typical in winter. From the beginning of August on, soil temperatures started increasing and they became higher in shallow soil layers compared to deeper layers. Large daily oscillations of soil temperatures were observed at $5 \mathrm{~cm}$ soil 


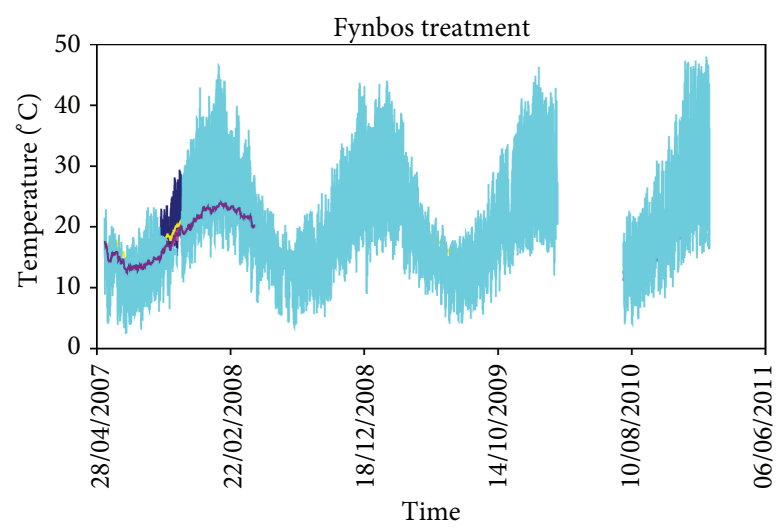

(a)

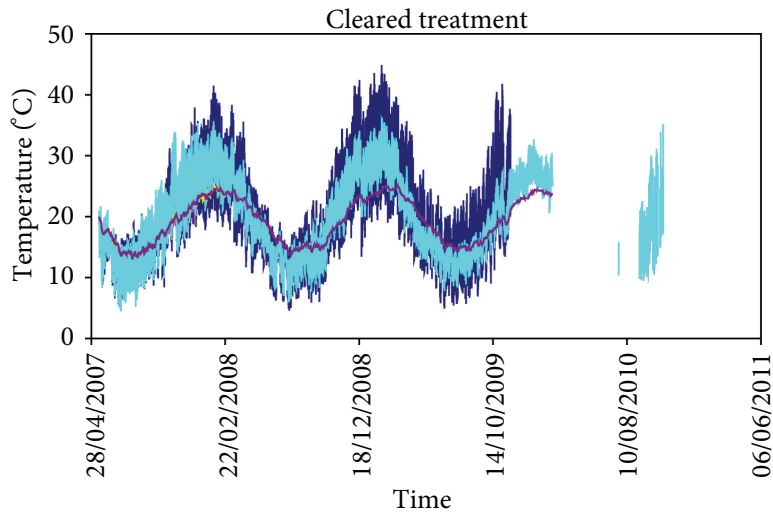

(b)

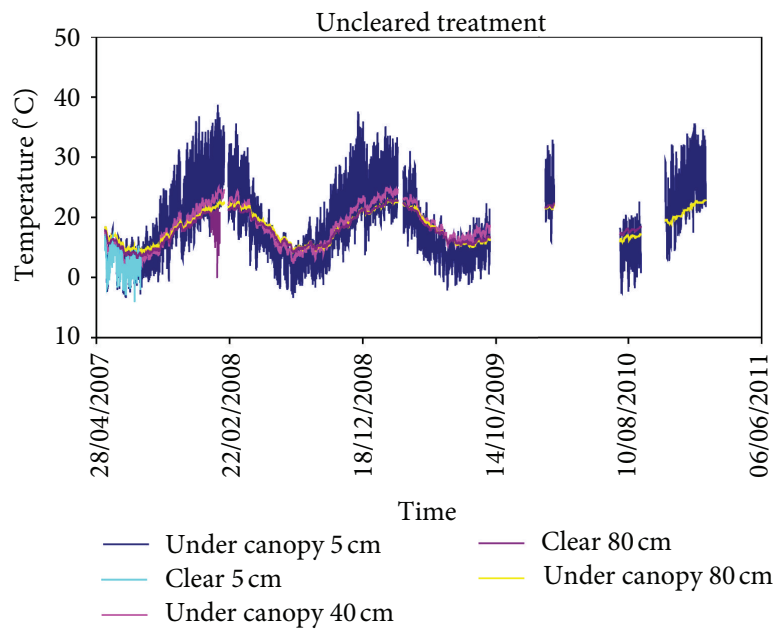

(c)

FiguRE 6: Soil temperatures measured from 1 May 2007 to 19 September 2011 with Echo-TE sensors at 5, 40, and $80 \mathrm{~cm}$ soil depth in three treatments at Riverlands Nature Reserve.

depth. These oscillations were most pronounced in the fynbos treatment, where the soil is covered by bushy vegetation, but it is more exposed to weather conditions compared to the other two treatments located in, or surrounded by, tree stands. More pronounced oscillations in daily temperature were also recorded by sensors located in the clear compared to those installed under the vegetation canopy. Weak daily oscillations in soil temperature were observed at $40 \mathrm{~cm}$, whilst practically no effect of variations in daily air temperature was observed at $80 \mathrm{~cm}$ soil depth. Oscillations in soil temperature were larger during summer compared to the winter months. The interruptions in records (Figure 6) were due to sensors' or loggers' malfunction.

Salinity recorded with Echo-TE sensors was inherently low as both the input of water into the system via rainfall and the groundwater are nonsaline. Readings of soil bulk and solution electrical conductivity were low, and they did not show any particular trends. Many records taken with the sensors showed no reading due to the low salinity levels in the soil.

\section{Dataset Description}

The dataset associated with this paper consists of 18 items which are described as follows.

Dataset Item 1 (Table). Daily rainfall data measured at Riverlands Nature Reserve for the period from 1 May 2007 to 19 September 2011. The data clearly indicated that the rainy season occurs from May to October with a prolonged drought spell usually from November to April.

Column 1: Date

Column 2: Daily Rainfall (mm)

Dataset Item 2 (Table). Hourly groundwater levels measured with Solinst logger installed in borehole RVLD1 at Riverlands Nature Reserve from 8 May 2007 to 14 September 2011. Hanging height and hanging elevation were $9.69 \mathrm{mbgl}$ and $103.77 \mathrm{~m}$ amsl, respectively, and starting from 14 October 2009 became $5.44 \mathrm{mbgl}$ and $108.02 \mathrm{~m}$ amsl, respectively. 
Logged and Barometer Compensated Water Level was measured in meters above reference point. Water Level 1 was measured in meters below ground level $(\mathrm{mbgl})$ and Water Level 2 in meters above mean sea level ( $\mathrm{m}$ amsl). Manual Measurement of Groundwater Level was in meters above mean sea level ( $\mathrm{m}$ amsl).

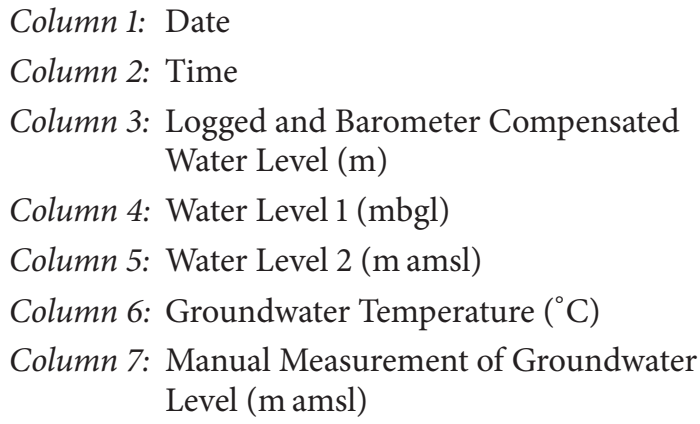

Dataset Item 3 (Table). Hourly groundwater levels measured with Solinst logger installed in borehole RVLD2 at Riverlands Nature Reserve from 16 July 2007 to 20 May 2009. Hanging height and hanging elevation were $6.78 \mathrm{mbgl}$ and $106.71 \mathrm{~m}$ amsl before March 2009, respectively, and became $6.61 \mathrm{mbgl}$ and $106.88 \mathrm{~m}$ amsl after March 2009, respectively. Moreover, hanging height became $5.20 \mathrm{mbgl}$ starting from 14 October 2009. Logged and Barometer Compensated Water Level was measured in meters above reference point. Water Level 1 was measured in meters below ground level (mbgl) and Water Level 2 in meters above mean sea level ( $\mathrm{m}$ amsl). Manual Measurement of Groundwater Level was in meters above mean sea level ( $\mathrm{m}$ amsl).

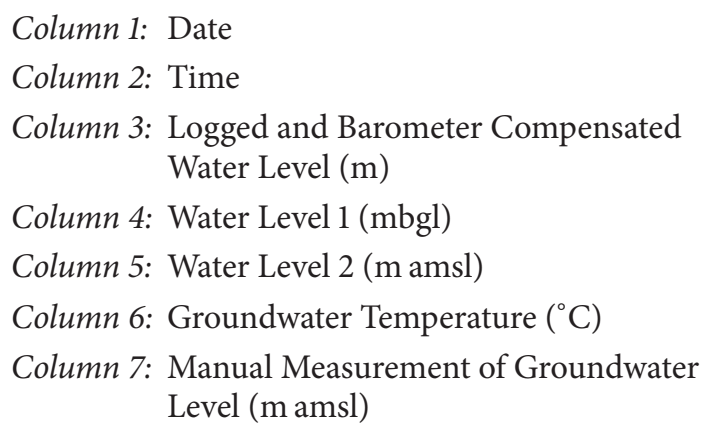

Dataset Item 4 (Table). Hourly groundwater levels measured with Solinst logger installed in borehole RVLD3 at Riverlands Nature Reserve from 23 April 2007 to 14 September 2011. Hanging height and hanging elevation were $3.82 \mathrm{mbgl}$ and $109.12 \mathrm{~m}$ amsl, respectively, and became $5.28 \mathrm{mbgl}$ and $107.66 \mathrm{~m}$ amsl starting from 14 October 2009, respectively. Logged and Barometer Compensated Water Level was measured in meters above reference point. Water Level 1 was measured in meters below ground level $(\mathrm{mbgl})$ and Water Level 2 in meters above mean sea level ( $\mathrm{m}$ amsl). Manual Measurement of Groundwater Level was in meters above mean sea level ( $\mathrm{m}$ amsl).

Column 1: Date

Column 2: Time

\author{
Column 3: Logged and Barometer Compensated \\ Water Level (m) \\ Column 4: Water Level 1 (mbgl) \\ Column 5: Water Level 2 ( $\mathrm{m}$ amsl) \\ Column 6: Groundwater Temperature $\left({ }^{\circ} \mathrm{C}\right)$ \\ Column 7: Manual Measurement of Groundwater \\ Level (m amsl)
}

Dataset Item 5 (Table). Hourly groundwater levels measured with Solinst logger installed in borehole RVLD4 at Riverlands Nature Reserve from 16 July 2007 to 30 September 2009. Hanging height and hanging elevation were $6.51 \mathrm{mbgl}$ and $106.43 \mathrm{~m}$ amsl, respectively, and became $6.14 \mathrm{mbgl}$ and $106.8 \mathrm{~m}$ amsl after May 2009, respectively. Logged and Barometer Compensated Water Level was measured in meters above reference point. Water Level 1 was measured in meters below ground level (mbgl) and Water Level 2 in meters above mean sea level ( $\mathrm{m}$ amsl). Manual Measurement of Groundwater Level was in meters above mean sea level (m amsl).

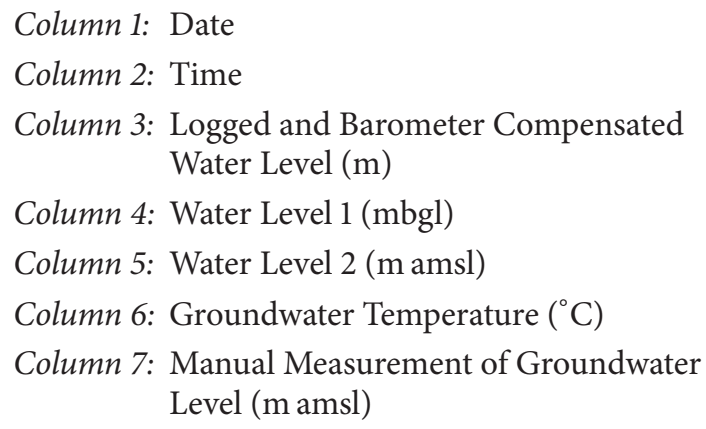

Dataset Item 6 (Table). Hourly groundwater levels measured with Solinst logger installed in borehole RVLD5 at Riverlands Nature Reserve from 8 May 2007 to 31 January 2011. Hanging height and hanging elevation were $19.28 \mathrm{mbgl}$ and $91.22 \mathrm{~m}$ amsl, respectively, became $19.08 \mathrm{mbgl}$ and $91.42 \mathrm{~m}$ amsl after May 2009, respectively, and then became $17.51 \mathrm{mbgl}$ and $92.99 \mathrm{~m}$ amsl starting from 14 October 2009. Logged and Barometer Compensated Water Level was measured in meters above reference point. Water Level 1 was measured in meters below ground level (mbgl) and Water Level 2 in meters above mean sea level ( $\mathrm{m}$ amsl). Manual Measurement of Groundwater Level was in meters above mean sea level ( $\mathrm{m}$ amsl).

Column 1: Date

Column 2: Time

Column 3: Logged and Barometer Compensated Water Level (m)

Column 4: Water Level 1 (mbgl)

Column 5: Water Level 2 ( $\mathrm{m}$ amsl)

Column 6: Groundwater Temperature $\left({ }^{\circ} \mathrm{C}\right)$

Column 7: Manual Measurement of Groundwater Level (m amsl) 
Dataset Item 7 (Table). Hourly groundwater levels measured with Solinst logger installed in borehole RVLD6 at Riverlands Nature Reserve from 8 May 2007 to 14 September 2011. Hanging height and hanging elevation were $3.04 \mathrm{mbgl}$ and $107.42 \mathrm{~m}$ amsl, respectively, became $2.8 \mathrm{mbgl}$ and $107.66 \mathrm{~m}$ amsl after May 2009, respectively, and then became $1.78 \mathrm{mbgl}$ and $108.68 \mathrm{~m}$ amsl starting from 14 October 2009. Logged and Barometer Compensated Water Level was measured in meters above reference point. Water Level 1 was measured in meters below ground level (mbgl) and Water Level 2 in meters above mean sea level (mamsl). Manual Measurement of Groundwater Level was in meters above mean sea level ( $\mathrm{m}$ amsl).

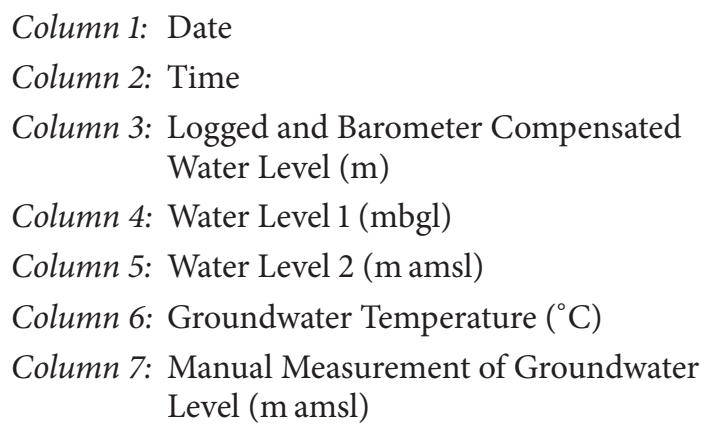

Dataset Item 8 (Table). Hourly groundwater levels measured with Solinst logger installed in borehole RVLD7 at Riverlands Nature Reserve from 8 May 2007 to 30 September 2009. Hanging height and hanging elevation were $9.98 \mathrm{mbgl}$ and $103.36 \mathrm{~m}$ amsl, respectively, and became $13.54 \mathrm{mbgl}$ and $106.92 \mathrm{~m}$ amsl, respectively. Logged and Barometer Compensated Water Level was measured in meters above reference point. Water Level 1 was measured in meters below ground level (mbgl) and Water Level 2 in meters above mean sea level ( $\mathrm{m}$ amsl). Manual Measurement of Groundwater Level was in meters above mean sea level ( $\mathrm{m}$ amsl).

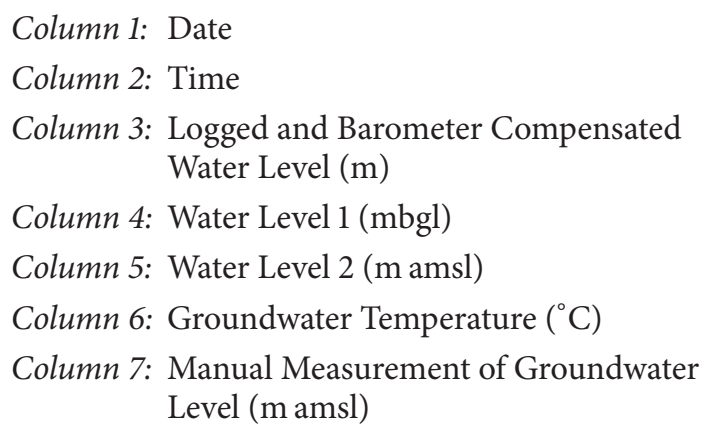

Dataset Item 9 (Table). Hourly groundwater levels measured with Solinst logger installed in borehole RVLD8 at Riverlands Nature Reserve from 16 July 2007 to 14 September 2011. Hanging height and hanging elevation were $7.02 \mathrm{mbgl}$ and $106.3 \mathrm{~m}$ amsl, respectively, became $6.95 \mathrm{mbgl}$ and $106.37 \mathrm{~m}$ amsl after March 2009, respectively, and then became $5.45 \mathrm{mbgl}$ and $107.87 \mathrm{~m}$ amsl starting from 14 October 2009. Logged and Barometer Compensated Water Level was measured in meters above reference point. Water Level 1 was measured in meters below ground level $(\mathrm{mbgl})$ and Water Level 2 in meters above mean sea level ( $\mathrm{m}$ amsl). Manual Measurement of Groundwater Level was in meters above mean sea level ( $\mathrm{m}$ amsl).

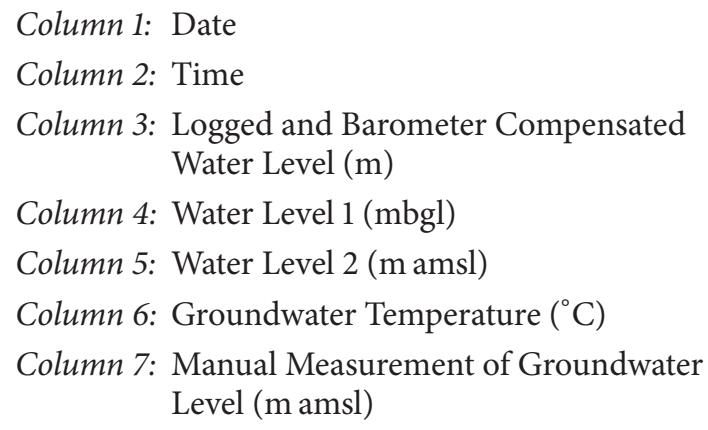

Dataset Item 10 (Table). Hourly groundwater levels measured with Solinst logger installed in borehole RVLD9 at Riverlands Nature Reserve from 9 May 2007 to 20 May 2009. Hanging height and hanging elevation were $4 \mathrm{mbgl}$ and $106.3 \mathrm{~m}$ amsl, respectively, and became $4.02 \mathrm{mbgl}$ and $107.38 \mathrm{~m}$ amsl after March 2009, respectively. Logged and Barometer Compensated Water Level was measured in meters above reference point. Water Level 1 was measured in meters below ground level (mbgl) and Water Level 2 in meters above mean sea level ( $\mathrm{m}$ amsl). Manual Measurement of Groundwater Level was in meters above mean sea level ( $\mathrm{m}$ amsl).

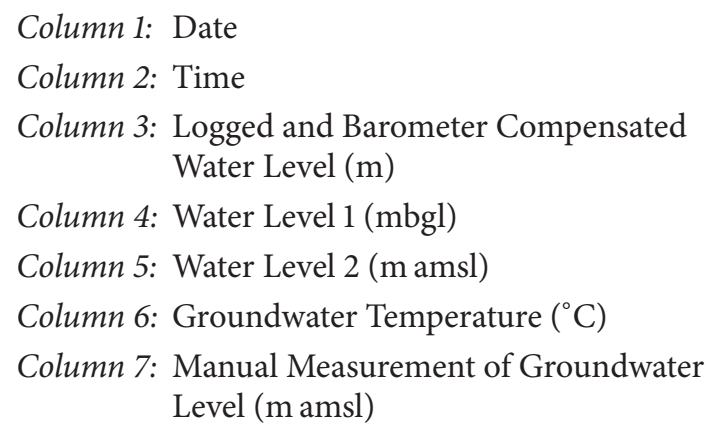

Dataset Item 11 (Table). Hourly groundwater levels measured with Solinst logger installed in borehole RVLD10 at Riverlands Nature Reserve from 9 May 2007 to 20 May 2009. Hanging height and hanging elevation were $5.73 \mathrm{mbgl}$ and $107.07 \mathrm{~m}$ amsl, respectively, and became $5.57 \mathrm{mbgl}$ and 107.23 m amsl after May 2009, respectively. Logged and Barometer Compensated Water Level was measured in meters above reference point. Water Level 1 was measured in meters below ground level (mbgl) and Water Level 2 in meters above mean sea level ( $\mathrm{m}$ amsl). Manual Measurement of Groundwater Level was in meters above mean sea level ( $\mathrm{m}$ amsl).

Column 1: Date

Column 2: Time

Column 3: Logged and Barometer Compensated Water Level (m)

Column 4: Water Level 1 (mbgl) 


\author{
Column 5: Water Level 2 ( $\mathrm{m}$ amsl) \\ Column 6: Groundwater Temperature $\left({ }^{\circ} \mathrm{C}\right)$ \\ Column 7: Manual Measurement of Groundwater \\ Level (m amsl)
}

Dataset Item 12 (Table). Hourly groundwater levels measured with Solinst logger installed in borehole RVLD11 at Riverlands Nature Reserve from 9 May 2007 to 7 September 2010. Hanging height and hanging elevation were $6.94 \mathrm{mbgl}$ and $105.96 \mathrm{~m}$ amsl, respectively, became $6.78 \mathrm{mbgl}$ and $106.12 \mathrm{~m}$ amsl after March 2009, respectively, and then became $5.83 \mathrm{mbgl}$ and $107.07 \mathrm{~m}$ amsl starting from 14 October 2009. On 4 May 2011, the borehole was blocked. Logged and Barometer Compensated Water Level was measured in meters above reference point. Water Level 1 was measured in meters below ground level (mbgl) and Water Level 2 in meters above mean sea level ( $\mathrm{m}$ amsl). Manual Measurement of Groundwater Level was in meters above mean sea level ( $\mathrm{m}$ amsl).

\section{Column 1: Date \\ Column 2: Time \\ Column 3: Logged and Barometer Compensated Water Level (m) \\ Column 4: Water Level 1 (mbgl) \\ Column 5: Water Level 2 ( $\mathrm{m}$ amsl) \\ Column 6: Groundwater Temperature $\left({ }^{\circ} \mathrm{C}\right)$ \\ Column 7: Manual Measurement of Groundwater Level (m amsl)}

Dataset Item 13 (Table). Hourly groundwater levels measured with Solinst logger installed in borehole RVLD12 at Riverlands Nature Reserve from 9 May 2007 to 14 September 2011. Hanging height and hanging elevation were $5.35 \mathrm{mbgl}$ and $107.45 \mathrm{~m}$ amsl, respectively, became $5.48 \mathrm{mbgl}$ and $107.32 \mathrm{~m}$ amsl after March 2009, respectively, and then became $4.15 \mathrm{mbgl}$ and $108.65 \mathrm{~m}$ amsl starting from 14 October 2009. Logged and Barometer Compensated Water Level was measured in meters above reference point. Water Level 1 was measured in meters below ground level (mbgl) and Water Level 2 in meters above mean sea level ( $\mathrm{m}$ amsl). Manual Measurement of Groundwater Level was in meters above mean sea level ( $\mathrm{m}$ amsl).

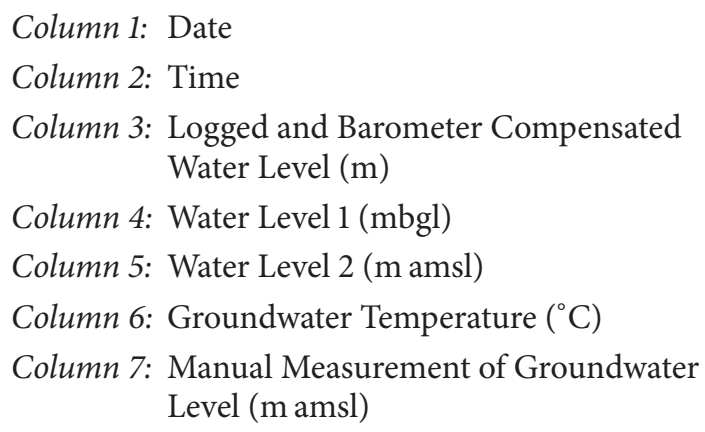

Dataset Item 14 (Table). Hourly groundwater levels measured with Solinst logger installed in borehole RVLD13 at Riverlands Nature Reserve from 8 May 2007 to 5 August 2008. Hanging height and hanging elevation were $5.73 \mathrm{mbgl}$ and $107.62 \mathrm{~m}$ amsl, respectively. Logged and Barometer Compensated Water Level was measured in meters above reference point. Water Level 1 was measured in meters below ground level (mbgl) and Water Level 2 in meters above mean sea level ( $\mathrm{m}$ amsl). Manual Measurement of Groundwater Level was in meters above mean sea level ( $\mathrm{m}$ amsl).

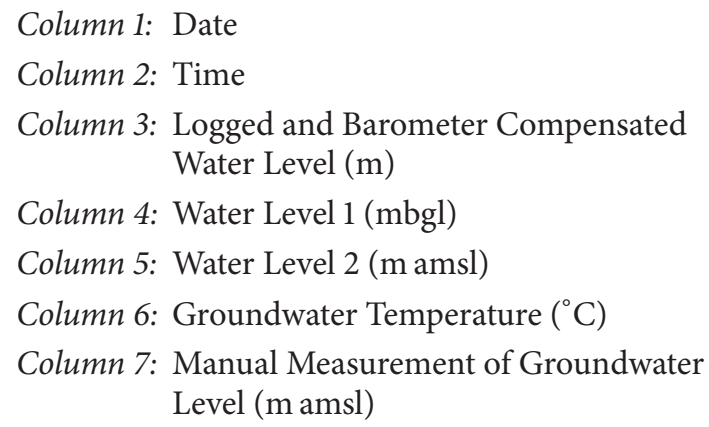

Dataset Item 15 (Table). Hourly groundwater levels measured with Solinst logger installed in borehole RVLD14 at Riverlands Nature Reserve from 9 May 2007 to 20 May 2009. Hanging height and hanging elevation were $5.68 \mathrm{mbgl}$ and $107.22 \mathrm{~m}$ amsl, respectively, and became $5.30 \mathrm{mbgl}$ and $107.6 \mathrm{~m}$ amsl after March 2009, respectively. After 25 February 2010, the collar was damaged and we could not access the borehole. Logged and Barometer Compensated Water Level was measured in meters above reference point. Water Level 1 was measured in meters below ground level $(\mathrm{mbgl})$ and Water Level 2 in meters above mean sea level (mamsl). Manual Measurement of Groundwater Level was in meters above mean sea level ( $\mathrm{m}$ amsl).

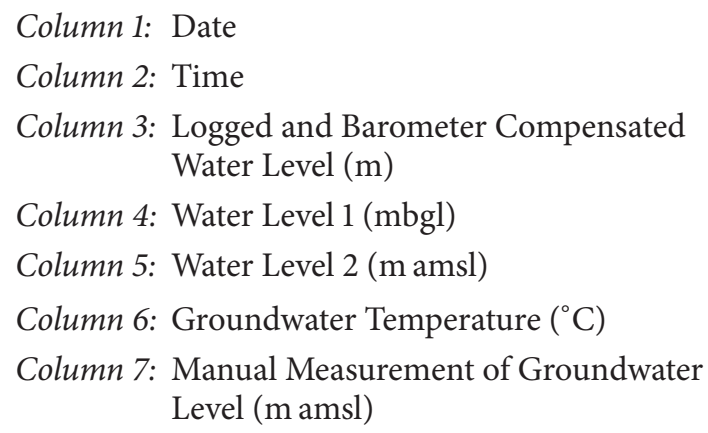

Dataset Item 16 (Table). Volumetric soil water content (expressed as percentage of soil water volume per bulk soil volume (\%) and as dimensionless fraction $\left.\left(\mathrm{m}^{3} \mathrm{~m}^{-3}\right)\right)$, soil temperature, and salinity measured at Riverlands from 15 May 2007 to 31 January 2011 with Echo-TE sensors at 5, 40, and $80 \mathrm{~cm}$ soil depth in the soil profile of fynbos treatment (EM3194 logger). Echo-TE sensor 1 was buried at $5 \mathrm{~cm}$ soil depth under plant canopy; sensor $2,40 \mathrm{~cm}$ soil depth under plant canopy; sensor 3,80 cm soil depth under plant canopy; 
sensor 4, $5 \mathrm{~cm}$ soil depth in the clear; sensor $5,80 \mathrm{~cm}$ soil depth in the clear.

$$
\begin{array}{ll}
\text { Column 1: } & \text { Date } \\
\text { Column 2: } & \text { Time } \\
\text { Column 3: } & \begin{array}{l}
\text { Volumetric Soil Water Content Percentage } \\
\text { of Sensor 1 (\%) }
\end{array} \\
\text { Column 4: } & \begin{array}{l}
\text { Volumetric Soil Water Content of Sensor 1 } \\
\left(\mathrm{m}^{3} \mathrm{~m}^{-3}\right)
\end{array}
\end{array}
$$

Column 5: $\quad$ Soil Temperature of Sensor $1\left({ }^{\circ} \mathrm{C}\right)$

Column 6: Soil Solution Electrical Conductivity of Sensor $1\left(\mathrm{dS} \mathrm{m}^{-1}\right)$

Column 7: Volumetric Soil Water Content Percentage of Sensor 2 (\%)

Column 8: Volumetric Soil Water Content of Sensor 2 $\left(\mathrm{m}^{3} \mathrm{~m}^{-3}\right)$

Column 9: $\quad$ Soil Temperature of Sensor $2\left({ }^{\circ} \mathrm{C}\right)$

Column 10: Soil Solution Electrical Conductivity of Sensor $2\left(\mathrm{dS} \mathrm{m}^{-1}\right)$

Column 11: Volumetric Soil Water Content Percentage of Sensor 3 (\%)

Column 12: Volumetric Soil Water Content of Sensor 3 $\left(\mathrm{m}^{3} \mathrm{~m}^{-3}\right)$

Column 13: Soil Temperature of Sensor $3\left({ }^{\circ} \mathrm{C}\right)$

Column 14: Soil Solution Electrical Conductivity of Sensor $3\left(\mathrm{dS} \mathrm{m}{ }^{-1}\right)$

Column 15: Volumetric Soil Water Content Percentage of Sensor 4 (\%)

Column 16: Volumetric Soil Water Content of Sensor 4 $\left(\mathrm{m}^{3} \mathrm{~m}^{-3}\right)$

Column 17: Soil Temperature of Sensor $4\left({ }^{\circ} \mathrm{C}\right)$

Column 18: Soil Solution Electrical Conductivity of Sensor $4\left(\mathrm{dS} \mathrm{m}^{-1}\right)$

Column 19: Volumetric Soil Water Content Percentage of Sensor 5 (\%)

Column 20: Volumetric Soil Water Content of Sensor 5 $\left(\mathrm{m}^{3} \mathrm{~m}^{-3}\right)$

Column 21: Soil Temperature of Sensor $5\left({ }^{\circ} \mathrm{C}\right)$

Column 22: Soil Solution Electrical Conductivity of Sensor $5\left(\mathrm{dS} \mathrm{m} \mathrm{m}^{-1}\right)$

Dataset Item 17 (Table). Volumetric soil water content (expressed as percentage of soil water volume per bulk soil volume (\%) and as dimensionless fraction $\left.\left(\mathrm{m}^{3} \mathrm{~m}^{-3}\right)\right)$, soil temperature, and salinity measured at Riverlands from 15 May 2007 to 1 November 2010 with Echo-TE sensors at 5, 40, and $80 \mathrm{~cm}$ soil depth in the soil profile of cleared treatment (EM3195 logger). Echo-TE sensor 1 was buried at $5 \mathrm{~cm}$ soil depth under plant canopy; sensor 2, $40 \mathrm{~cm}$ soil depth under plant canopy; sensor 3,80 cm soil depth under plant canopy; sensor $4,5 \mathrm{~cm}$ soil depth in the clear; sensor $5,80 \mathrm{~cm}$ soil depth in the clear.

\section{Column 1: Date}

Column 2: Time

Column 3: Volumetric Soil Water Content Percentage of Sensor 1 (\%)

Column 4: Volumetric Soil Water Content of Sensor 1 $\left(\mathrm{m}^{3} \mathrm{~m}^{-3}\right)$

Column 5: Soil Temperature of Sensor $1\left({ }^{\circ} \mathrm{C}\right)$

Column 6: Soil Solution Electrical Conductivity of Sensor $1\left(\mathrm{dS} \mathrm{m}^{-1}\right)$

Column 7: Volumetric Soil Water Content Percentage of Sensor 2 (\%)

Column 8: Volumetric Soil Water Content of Sensor 2 $\left(\mathrm{m}^{3} \mathrm{~m}^{-3}\right)$

Column 9: $\quad$ Soil Temperature of Sensor $2\left({ }^{\circ} \mathrm{C}\right)$

Column 10: Soil Solution Electrical Conductivity of Sensor $2\left(\mathrm{dS} \mathrm{m}^{-1}\right)$

Column 11: Volumetric Soil Water Content Percentage of Sensor 3 (\%)

Column 12: Volumetric Soil Water Content of Sensor 3 $\left(\mathrm{m}^{3} \mathrm{~m}^{-3}\right)$

Column 13: Soil Temperature of Sensor $3\left({ }^{\circ} \mathrm{C}\right)$

Column 14: Soil Solution Electrical Conductivity of Sensor $3\left(\mathrm{dS} \mathrm{m}^{-1}\right)$

Column 15: Volumetric Soil Water Content Percentage of Sensor 4 (\%)

Column 16: Volumetric Soil Water Content of Sensor 4 $\left(\mathrm{m}^{3} \mathrm{~m}^{-3}\right)$

Column 17: Soil Temperature of Sensor $4\left({ }^{\circ} \mathrm{C}\right)$

Column 18: Soil Solution Electrical Conductivity of Sensor $4\left(\mathrm{dS} \mathrm{m}^{-1}\right)$

Column 19: Volumetric Soil Water Content Percentage of Sensor 5 (\%)

Column 20: Volumetric Soil Water Content of Sensor 5 $\left(\mathrm{m}^{3} \mathrm{~m}^{-3}\right)$

Column 21: Soil Temperature of Sensor $5\left({ }^{\circ} \mathrm{C}\right)$

Column 22: Soil Solution Electrical Conductivity of Sensor $5\left(\mathrm{dS} \mathrm{m}^{-1}\right)$

Dataset Item 18 (Table). Volumetric soil water content (expressed as percentage of soil water volume per bulk soil volume (\%) and as dimensionless fraction $\left(\mathrm{m}^{3} \mathrm{~m}^{-3}\right)$ ), soil temperature, and salinity measured at Riverlands from 17 May 2007 to 31 January 2011 with Echo-TE sensors at 5, 40, and $80 \mathrm{~cm}$ soil depth in the soil profile of uncleared treatment (EM3193 logger). Echo-TE sensor 1 was buried at $5 \mathrm{~cm}$ soil 
depth under plant canopy; sensor 2, $40 \mathrm{~cm}$ soil depth under plant canopy; sensor 3,80 cm soil depth under plant canopy; sensor $4,5 \mathrm{~cm}$ soil depth in the clear; sensor $5,80 \mathrm{~cm}$ soil depth in the clear.

$$
\begin{aligned}
& \text { Column 1: Date } \\
& \text { Column 2: Time } \\
& \text { Column 3: Volumetric Soil Water Content Percentage } \\
& \text { of Sensor } 1 \text { (\%) } \\
& \text { Column 4: Volumetric Soil Water Content of Sensor } 1 \\
& \left(\mathrm{~m}^{3} \mathrm{~m}^{-3}\right)
\end{aligned}
$$

Column 9: $\quad$ Soil Temperature of Sensor $2\left({ }^{\circ} \mathrm{C}\right)$

Column 10: Soil Solution Electrical Conductivity of Sensor $2\left(\mathrm{dS} \mathrm{m} \mathrm{m}^{-1}\right)$

Column 11: Volumetric Soil Water Content Percentage of Sensor 3 (\%)

Column 12: Volumetric Soil Water Content of Sensor 3 $\left(\mathrm{m}^{3} \mathrm{~m}^{-3}\right)$

Column 13: Soil Temperature of Sensor $3\left({ }^{\circ} \mathrm{C}\right)$

Column 14: Soil Solution Electrical Conductivity of Sensor $3\left(\mathrm{dS} \mathrm{m}^{-1}\right)$

Column 15: Volumetric Soil Water Content Percentage of Sensor 4 (\%)

Column 16: Volumetric Soil Water Content of Sensor 4 $\left(\mathrm{m}^{3} \mathrm{~m}^{-3}\right)$

Column 17: Soil Temperature of Sensor $4\left({ }^{\circ} \mathrm{C}\right)$

Column 18: Soil Solution Electrical Conductivity of Sensor $4\left(\mathrm{dS} \mathrm{m}^{-1}\right)$

Column 19: Volumetric Soil Water Content Percentage of Sensor 5 (\%)

Column 20: Volumetric Soil Water Content of Sensor 5 $\left(\mathrm{m}^{3} \mathrm{~m}^{-3}\right)$

Column 21: Soil Temperature of Sensor $5\left({ }^{\circ} \mathrm{C}\right)$

Column 22: Soil Solution Electrical Conductivity of Sensor $5\left(\mathrm{dS} \mathrm{m}{ }^{-1}\right)$

\section{Concluding Remarks}

Continuous long-term monitoring of all environmental components (weather, soil water content, and groundwater) is essential for understanding natural systems and calibrating models. Intensive monitoring and hydrological data, especially long time series, are scarce. In this study, we provided five years of continuous records of rainfall, soil water, and groundwater in areas with endemic vegetation and invaded by alien species. This is invaluable in order to gain understanding of natural systems, contribute to ecosystem conservation, and ultimately quantify water balance processes accurately. The data can be applied in water balance and evapotranspiration studies, unsaturated zone flux studies, soil temperature profile studies, and rainfall-groundwater level response analysis and for calibrating and validating a wide range of hydrological models.

\section{Dataset Availability}

The dataset associated with this Dataset Paper is dedicated to the public domain using the CC0 waiver and is available at http://dx.doi.org/10.7167/2013/724819/dataset. In addition, rainfall data; groundwater level data; and volumetric soil water contents, soil temperature, and electrical conductivity data are available on CDs appended to Water Research Commission Report no. K5/1909 [20], Pretoria, South Africa (they can be ordered from http://www.wrc.org.za/ or directly from the authors).

\section{Conflict of Interests}

The authors declare that there is no conflict of interests.

\section{Acknowledgments}

The authors acknowledge the Water Research Commission (Pretoria, South Africa) for funding the research and the field equipment and also the Riverlands Nature Reserve (managed by Cape Nature Conservation) for providing the study site and the daily rainfall data.

\section{References}

[1] J. Alcamo, M. Flörke, and M. Märker, "Future long-term changes in global water resources driven by socio-economic and climatic changes," Hydrological Sciences Journal, vol. 52, no. 2, pp. 247-275, 2007.

[2] D. B. Lindenmayer and G. E. Likens, "Adaptive monitoring: a new paradigm for long-term research and monitoring," Trends in Ecology and Evolution, vol. 24, no. 9, pp. 482-486, 2009.

[3] I. A. Shiklomanov, "Appraisal and assessment of world water resources," Water International, vol. 25, no. 1, pp. 11-32, 2000.

[4] C. Y. Xu and V. P. Singh, "Review on regional water resources assessment models under stationary and changing climate," Water Resources Management, vol. 18, no. 6, pp. 591-612, 2004.

[5] D. M. Richardson, P. Pyšek, M. Rejmánek, M. G. Barbour, F. Dane Panetta, and C. J. West, "Naturalization and invasion of alien plants: concepts and definitions," Diversity and Distributions, vol. 6, no. 2, pp. 93-107, 2000.

[6] P. M. Vitousek, H. A. Mooney, J. Lubchenco, and J. M. Melillo, "Human domination of Earth's ecosystems," Science, vol. 277, no. 5325, pp. 494-499, 1997.

[7] D. Pimentel, R. Zuniga, and D. Morrison, "Update on the environmental and economic costs associated with alien-invasive species in the United States," Ecological Economics, vol. 52, no. 3, pp. 273-288, 2005.

[8] D. C. le Maitre, D. M. Richardson, and R. A. Chapman, "Alien plant invasions in South Africa: driving forces and the human 
dimension," South African Journal of Science, vol. 100, no. 1-2, pp. 103-112, 2004.

[9] N. Dassonville, S. Vanderhoeven, V. Vanparys, M. Hayez, W. Gruber, and P. Meerts, "Impacts of alien invasive plants on soil nutrients are correlated with initial site conditions in NW Europe," Oecologia, vol. 157, no. 1, pp. 131-140, 2008.

[10] D. C. le Maitre, D. B. Versfeld, and R. A. Chapman, “The impact of invading alien plants on surface water resources in South Africa: a preliminary assessment," Water $S A$, vol. 26, no. 3, pp. 397-408, 2000.

[11] B. W. van Wilgen, D. M. Richardson, D. C. le Maitre, C. Marais, and D. Magadlela, "The economic consequences of alien plant invasions: examples of impacts and approaches to sustainable management in south Africa," Environment, Development and Sustainability, vol. 3, no. 2, pp. 145-168, 2001.

[12] P. Goldblatt and J. C. Manning, "Plant diversity of the Cape region of southern Africa," Annals of the Missouri Botanical Garden, vol. 89, no. 2, pp. 281-302, 2002.

[13] B. Hewitson, M. Tadross, and C. Jack, "Scenarios from the University of Cape Town," in Climate Change and Water Resources in Southern Africa: Studies on Scenarios, Impacts, Vulnerabilities and Adaptation, R. E. Schulze, Ed., pp. 39-56, Water Research Commission, Pretoria, South Africa, 2005.

[14] IPCC, Climate Change 2007: Synthesis Report, R.K. Pachauri and A. Reisinger, Eds., IPCC, Geneva, Switzerland, 2007.

[15] L. Hannah, G. Midgley, G. Hughes, and B. Bomhard, "The view from the cape: extinction risk, protected areas, and climate change," BioScience, vol. 55, no. 3, pp. 231-242, 2005.

[16] J. Turpie, "The role of resource economics in the control of invasive alien plants in South Africa," South African Journal of Science, vol. 100, no. 1-2, pp. 87-93, 2004.

[17] DWAF, The Working for Water Programme: Annual Report 1996/97, Department of Water Affairs and Forestry, Pretoria, South Africa, 1997.

[18] N. Z. Jovanovic, A. Hon, S. Israel et al., "Nitrate leaching from soils cleared of alien vegetation," Water Research Commission Report 1696/09, Water Research Commission, Pretoria, South Africa, 2009.

[19] N. Z. Jovanovic, S. Israel, G. Tredoux et al., "Nitrogen dynamics in land cleared of alien vegetation (Acacia Saligna) and impacts on groundwater at Riverlands nature reserve (Western Cape, South Africa)," Water SA, vol. 35, no. 1, pp. 37-44, 2009.

[20] N. Z. Jovanovic, R. D. H. Bugan, S. Israel et al., "Reducing uncertainties of evapotranspiration and preferential flow in the estimation of groundwater recharge," Water Research Commission Report K5/1909, Water Research Commission, Pretoria, South Africa, 2012.

[21] N. Z. Jovanovic, R. D. H. Bugan, and S. Israel, "Quantifying the evapotranspiration component of the water balance of Atlantis Sand Plain Fynbos (South Africa)," in Evapotranspiration-An Overview, S. G. Alexandris and R. Stricevic, Eds., pp. 39-59, InTech Open Access Publishing, Vienna, Austria, 2013.

[22] N. Z. Jovanovic, S. Israel, C. Petersen et al., "Optimized monitoring of groundwater-surface water-atmospheric parameters for enhanced decision-making at a local scale," Water Research Commission Report 1846/1/11, Water Research Commission, Pretoria, South Africa, 2011.

[23] A. G. Rebelo, C. Boucher, N. Helme, L. Mucina, and M. C. Rutherford, "Fynbos biome," in The Vegetation of South Africa, Lesotho and Swaziland, L. Mucina and M. C. Rutherford, Eds., vol. 19 of Strelitzia, pp. 53-219, South African National Biodiversity Institute, Pretoria, South Africa, 2006. 

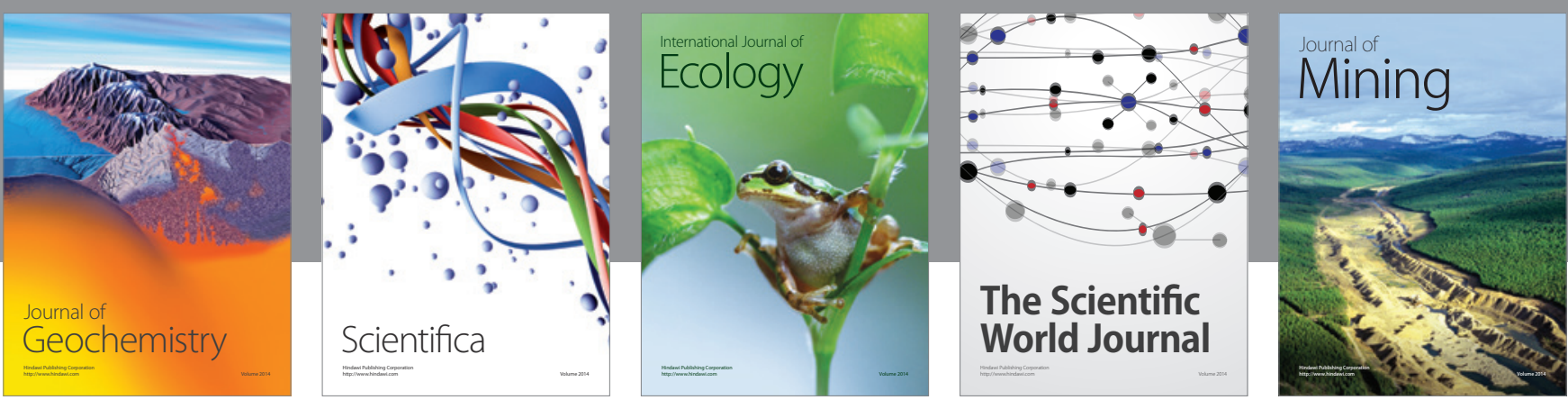

The Scientific World Journal
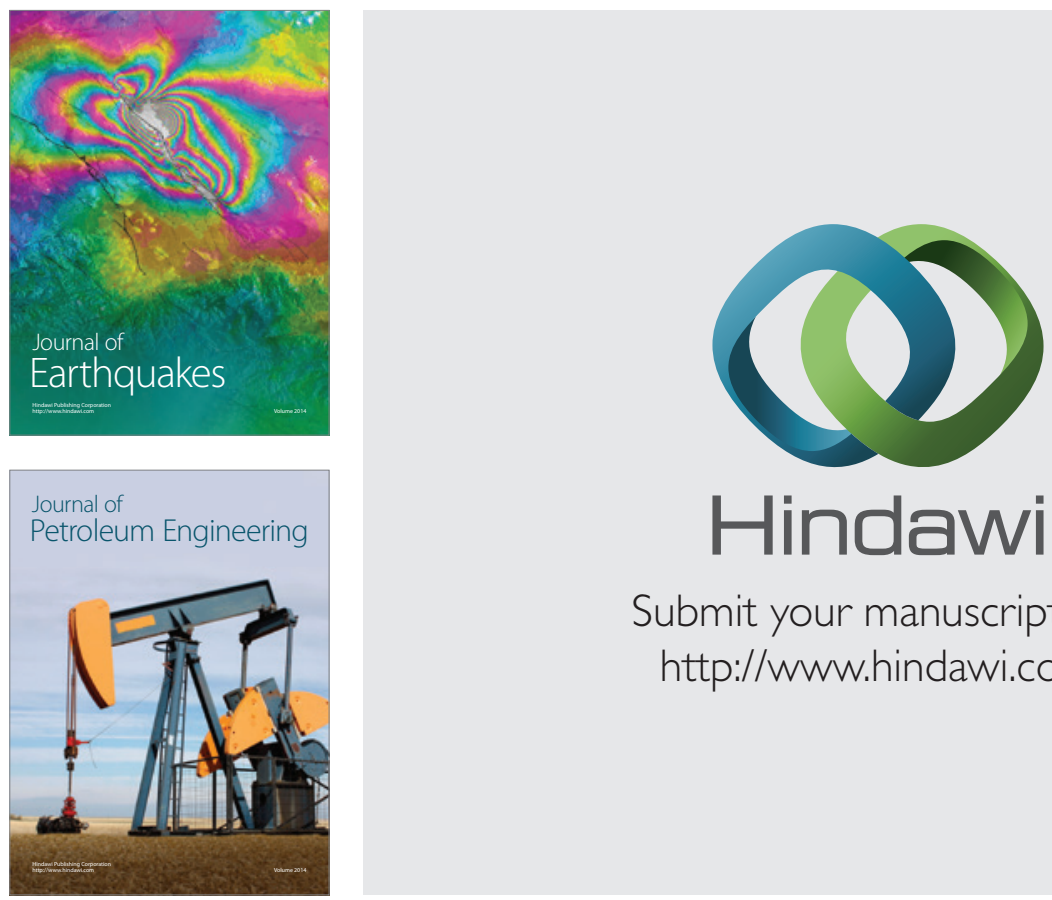

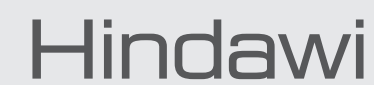

Submit your manuscripts at

http://www.hindawi.com
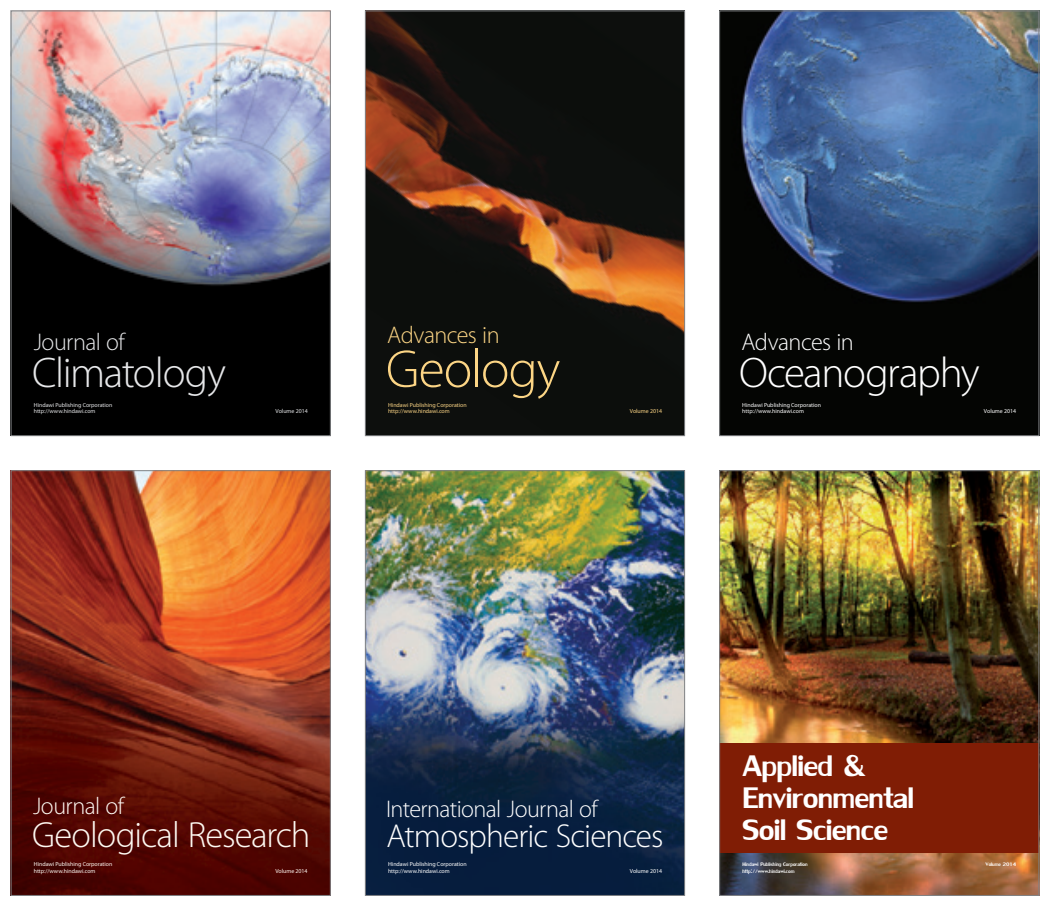
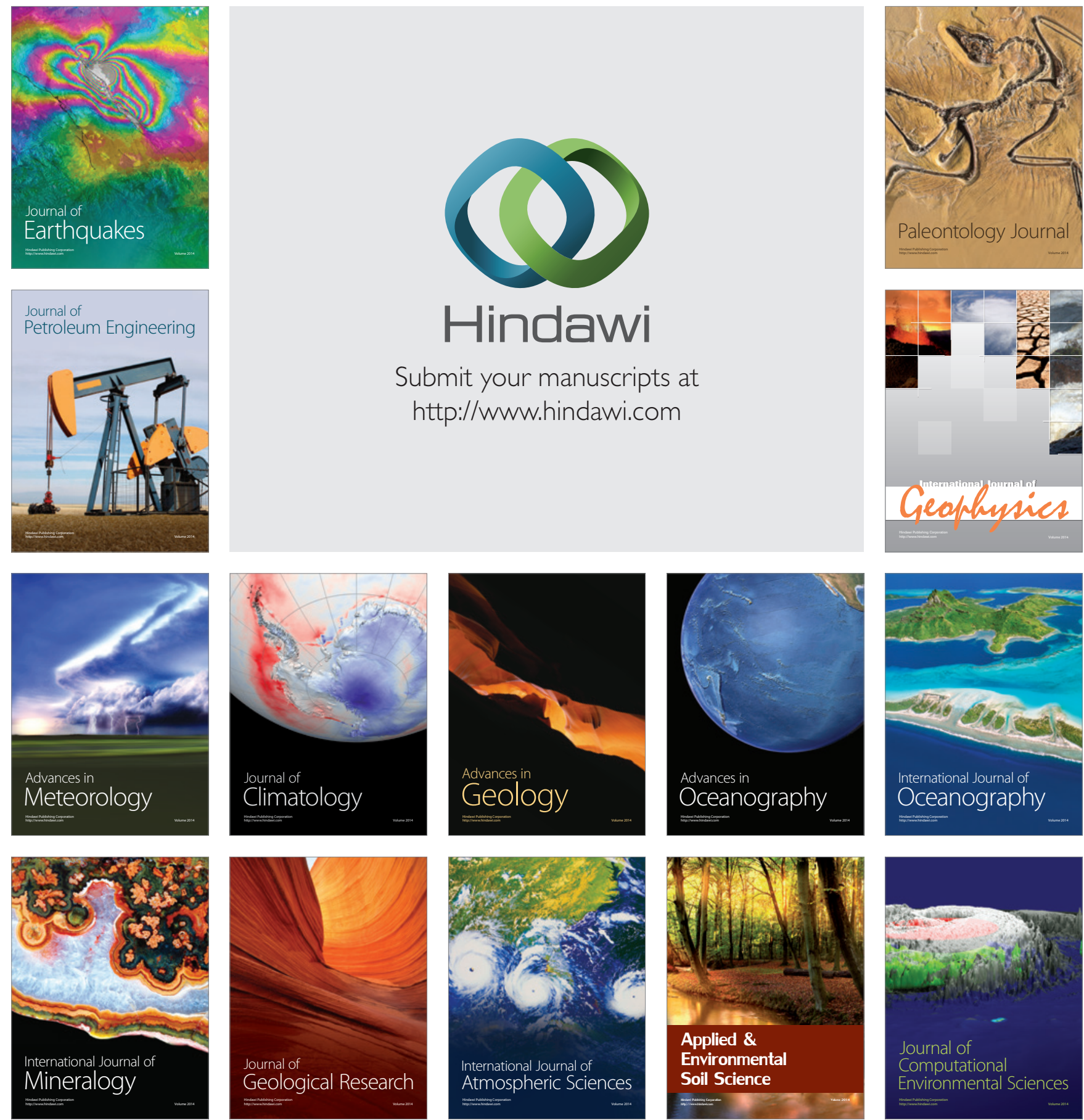